\title{
Modern problems in the sphere of retail trade services in the book production market
}

\author{
Lyudmila Protasova \\ D.Sc, professor, \\ head of the department of quality management \\ of Ural state economic university \\ Yekaterinburg, Russia \\ ukpt@,usue.ru
}

\author{
Tatyana Minina \\ $\mathrm{PhD}$, \\ associate professor of the department of marketing and \\ international management \\ of Ural state economic university \\ Yekaterinburg, Russia \\ mininatb@yandex.ru
}

\author{
Konstantin Tedeev \\ Postgraduate student \\ of the department of quality management \\ of Ural state economic university \\ Yekaterinburg, Russia \\ tedeyev@mail.ru
}

\begin{abstract}
The article is devoted to the research of the problems of modern Russian retail trade by the example of regional retail trade. The complexity of the work of Russian enterprises in the context of the economic crisis is considered, options for optimizing the supply chain management system are proposed.
\end{abstract}

Keywords - logistics, retail, book trading, carriage, stock running, supply chain management

\section{INTRODUCTION}

In work [1] it is noted that trade, which has recently occupied a leading position in the structure of the Russian economy, is losing its positions. So, the retail trade turnover at the beginning of 2016 amounted to 2125.1 billion rubles, at the same time in 2015 it amounted to $27,575.7$ billion rubles, the reduction is significant.

Let's analyze the current state of the Russian and regional book products market, determine the problems and prospects for the development of retail trade.

Despite the fact that, as before, about $80 \%$ of book products are sold in retail trade, due to the economic crisis in the country there are problems. In particular, in work [2] it is noted that the slowdown in consumption rates among Russian citizens, the transition to austerity and the focus on the acquisition of essential goods adversely affect the book production market.

According to the magazine "Book Industry", in 2014. the volume of the book market in Russia amounted to 50.74 billion rubles. without the volume of purchases by budget organizations and the volume of unstructured sales and 75.50 billion rubles taking into account these volumes. So the volume of the Russian book market in money terms increased in 2014 in comparison with 2013 by $0.71 \%$, mostly due to a significant increase of in the Internet trading channel and unlearned retail (FMCG). Nevertheless, the turnover of the book industry in the printed book as a whole declined in 2014 on $3,22 \%[2]$.

It should be noted significant differences in the analysis of the dynamics of the number of buyers of central and regional bookselling enterprises. So, if from 2009 to 2011. there was an increase in the number of buyers in bookshops, then in the last three years there was an outflow especially in the regions, there was a decrease in sales by $13 \%$. [2]. So in the Urals Federal District in 2014. books were sold for a total of 4109408.4 thousand rubles.

In addition, the market is developing audiobooks and e-books. According to the studies, presented in the magazine "Book Industry", in 2015 legal market of audiobooks demonstrated growth rates (+ $127 \%$ to the level of 2014), and the proportion of readers of books in electronic format grew by $32.7 \%$. According to the magazine "Book Industry", in $2015 \mathrm{~g}$ of. the volume of the book market in Russia amounted to 51.82 billion rubles without the volume of purchases by budget organizations and the volume of unstructured sales and 73.55 billion rubles taking into account these volumes [3]. Sales of books in the Urals Federal District in 2015 amounted to 4438415.4 thousand rubles.

\section{RESULTS AND DISCUSSION}

As a result of deep research of Russian retail trade and book production market, we summarized logistical problems in the retail trade services of books in Russia (see Table 1). 
Table 1 - Logistics problems in the sphere of retail trade in the book products market of Russia

\begin{tabular}{|l|l|l|l|}
\hline \multicolumn{1}{|c|}{ Infrastructural } & \multicolumn{1}{|c|}{ Organizational } & \multicolumn{1}{c|}{ Information } & \multicolumn{1}{c|}{ Economic } \\
\hline $\begin{array}{l}\text { Underdevelopment of transport } \\
\text { infrastructure. Low density of } \\
\text { railways. Low length and quality of } \\
\text { highways. }\end{array}$ & $\begin{array}{l}\text { Absence of an integrated } \\
\text { approach to the management of } \\
\text { stocks of book products along the } \\
\text { whole path of their movement and } \\
\text { distribution between the links of } \\
\text { the logistical system. }\end{array}$ & $\begin{array}{l}\text { Low-efficient information } \\
\text { support of cargo transportation. }\end{array}$ & $\begin{array}{l}\text { Decrease in incomes of the } \\
\text { population and demand for } \\
\text { book production. }\end{array}$ \\
\hline $\begin{array}{l}\text { Insufficient number of multimodal } \\
\text { carriers capable of organizing the } \\
\text { process of delivery of products to } \\
\text { the regions by different modes of } \\
\text { transport. }\end{array}$ & $\begin{array}{l}\text { Reductions in the space allocated } \\
\text { for books and the number of } \\
\text { books presented in the trade halls, } \\
\text { due to the increase in the range of } \\
\text { non-book goods. }\end{array}$ & $\begin{array}{l}\text { Redundancy of information in } \\
\text { accounting, statistical and } \\
\text { operational trade documents. }\end{array}$ & $\begin{array}{l}\text { Increasing the share of book } \\
\text { sales over the Internet - } \\
\text { shopsbook ru, read.ru, } \\
\text { ozon.ru. }\end{array}$ \\
\hline $\begin{array}{l}\text { Concentration of large book } \\
\text { producers in the European part of } \\
\text { Russia. }\end{array}$ & $\begin{array}{l}\text { Use of the Internet channel by } \\
\text { publishers as one of the directions } \\
\text { of the marketing policy. }\end{array}$ & $\begin{array}{l}\text { The inability of existing forms } \\
\text { of statistical and accounting } \\
\text { reporting to identify the } \\
\text { parameters needed to solve } \\
\text { logistics tasks, including } \\
\text { inventory management. }\end{array}$ & $\begin{array}{l}\text { Sale of books as related } \\
\text { products in trade networks } \\
\text { "Auchan", "Metro", } \\
\text { "OK","Lenta","Magnit", } \\
\text { "Globus". }\end{array}$ \\
\hline $\begin{array}{l}\text { Undeveloped logistical } \\
\text { infrastructure of book distribution }\end{array}$ & $\begin{array}{l}\text { Sales of books by publishers } \\
\text { through their own site and among } \\
\text { social media "Facebook" } \\
\text { "VKontakte", "Twitter". }\end{array}$ & $\begin{array}{l}\text { Low level of automation of } \\
\text { information flows in retail } \\
\text { booksellers. }\end{array}$ & $\begin{array}{l}\text { Bankruptcy of individual } \\
\text { bookselling chains. }\end{array}$ \\
\hline
\end{tabular}

Increased the timing of book production from 158 to 756 days, from retail outlets freeze substantial funds in stocks, book publishers have also noted an increase in returns of products. Ensuring the sustainable functioning and development of the Russian book retail trade market is an important task, especially during the difficult economic situation in the country, which can be facilitated by the introduction of logistics management mechanisms in retail trade.

Changing preferences of buyers by types of book products, so in 2014 sales of scientific, educational and children's literature increased, and fiction and reference books fell. For the price: in 2015 in comparison with 2008 ehe demand for books in the cost of 301 to 500 rubles increased at $7 \%$ and cost from 501 to 1000 rubles by $5 \%$. Through the channels of book distribution: if from 2009 to 2011. there was an increase in the number of buyers in bookshops, then in the last three years there has been an outflow especially in the regions on average by $13 \%$, buyers prefer to buy books in an online store.

Retail market of the Sverdlovsk region, in spite of the foreign policy events occurred and the subsequent economic crisis in the country in 2015 showed growth compared to 2014. Nevertheless, the crisis phenomena were manifested in particular in the reduction of the share of small and medium-sized enterprises in the total volume by $1.8 \%$. The growth in the volume of the market was mainly due to the increase in the number and turnover of large retail chains.

Moving from the general to the particular, we will analyze the bookselling market in Yekaterinburg. One of the main problems in the retail book trade market of the city of Yekaterinburg is the closure of such well-known shops in the city as: "Bookstore №14", "Tsarkniga", "Las Books", and the last three stores ceased operations in the pre-crisis period (2012-2013), that is, the main reason for their closure was excessive competition. It should be noted that the investors of the "King of Books" were influential Ural businessmen, and the "Las Books" company belonged to the largest book-trade company "Top Book" in Russia. However, even such a powerful support did not help to stay in the given stores on the market.
The main factor that had a negative impact was that these stores were concentrated in the center of the city, within a radius of several hundred meters around the center of the city. With a fairly wide range and reasonable prices, they still significantly lost in these aspects of the "Dom knigi" and the buyers did not see the point of visiting them when within a hundred meters of them was the "Dom knigi" offering an even wider range of goods and lower prices.

Presshouse-Ural chose another market strategy - instead of forcing competitive competitors to strong competitors such as the Dom knigi and 100,000 books, they filled an empty niche in the city and began to open small stores in the "Good News" network in places of mass congestion of people: airports, universities, large stores. Since all stores of this trade network are located at a significant distance from competitors, the company does not have to incur losses, getting involved in the competition with large book trade enterprises. Thus, "Good News", pursuing the main goal - profitmaking, also solve an important social problem - providing the population with literature. At the same time, other large book trade enterprises also lost their positions: the popular 100,000-book store, located at Lenin's address, 49, was closed. With the economic crisis, the Top-Book Company, the largest bookseller in Russia . However, a number of enterprises, for example, LLC "Dom knigi" and LLC "Presshouse-Ural", not only did not lose their position in the market, but also strengthened it by opening several new branches.

Apparently, the economic crisis exacerbated the accumulated problems in regional retail trade. To a lesser extent, the consequences of the crisis were experienced by FMCG enterprises, to a greater extent - enterprises that sell goods of periodic demand. Despite the fact that, according to polls, most Russians prefer not to save on buying books, a reduction in incomes and a rise in prices for print media has had a significant impact on the state of book trade.

Until 2014, the problems that existed in the regional book trade were blocked by an inadequate supply. Since the total number of bookstores in Russia without exceeding 3000, then to 100000 Russians it come only 2 shops. For comparison, in Austria there are 
200 stores for 100 thousand inhabitants, in Germany and Spain about 100 stores, in the United States of America - less than 50. Excess demand, and as a consequence high incomes, cover losses that companies suffered from management errors, unsatisfactory assortment and price policy, poor marketing support, as well as the general economic problems inherent in Russian regional trade

The economic crisis and the ensuing decline in demand in retail trade have exposed the problems. The supply-demand ratio for the book products reached the average European index, however, the organization of trade remained at a rather low level. In addition, due to illiterate management, new problems have been imposed on other problems.

So, for example, earlier to satisfy a high level of demand, the enterprises created over-stocks, the warehouses were overstocked with stale goods. Part of the problem solved the possibility of returning products. This possibility is currently provided by most major Russian publishers. Publishers stimulate the sale of products, creating a feeling of relative security for booksellers, reducing the risk of illiquid formation. Returns are popular in book trade, but the use of this tool is not always effective.

On the one hand, book dealers, knowing that they can make a return of unsold products, feel some freedom and can buy goods with a large margin of insurance. This allows them to fully meet the demand, which, on the one hand, brings a high profit to all participants in the supply chain and, on the other hand, creates a favorable image for the seller.

However, the negative role of reverse logistics for both participants in the supply chain is also evident. Publishers suffer losses due to the fact that they return the cost of unsold goods (usually payment is made at the expense of reducing the cost of future supplies), and also have to return books for processing. Store returns can also be disadvantageous, especially for regional businesses. Transport costs for the return of books to suppliers can significantly exceed losses from writing off books. Therefore, booksellers often give unsold books as donations to various social organizations or simply surrender. All three parties pay for such an ineffective assortment policy: the publisher and seller lose profits, the buyer incurs additional costs when buying books.

Due to the fact that the formation of excess stocks is the most important of the problems of regional book trade, many enterprises literally rushed from the extreme to the extreme and decided to minimize the reserves. However, a sharp decline in inventories for regional enterprises can result in a loss of quality of customer service and, as a result, an outflow of buyers and a decline in sales.

The only possible strategy for regional retailers is to optimize inventory. When calculating the size of the optimal stock for book trade enterprises, it is necessary to consider the following factors: the size of the need for certain books per unit of time; periodicity of demand for certain books; psychology of consumer perception of the breadth of the range and the absence of popular books on sale; remoteness of booksellers from trade enterprises; the availability and size of the warehouse premises of a commercial enterprise.

\section{MATERIALS AND METHODS (MODEL)}

According to numerous of our studies, we came to the conclusion that in the retail book trade the unreleased stocks should be written off. Management of medium- and low-turnover groups of stocks does not require the use of any special approaches. Maintaining stocks of these groups of goods at the level of the average sales for the interval between deliveries will let the enterprise on the one hand to provide the average demand, and on the other hand, to avoid extra costs for transportation and storage unclaimed products.

If you exceed the average volume of demand, the company will face a deficit, however, given the specificity of the book trade, no retail bookselling business can avoid shortages of some product groups. Therefore, the question here may not be the complete elimination of the shortage of goods, but only the finding of a reasonable balance between the quality of consumer services, expressed in terms of inventory management theory, in the probability of being in the place of sale of goods necessary to the consumer, and the costs associated with the purchase, transportation, storage and possible write-off or return of stocks.

A special approach is required for a group of overturned stocks. Here, the enterprise should strive to meet the demand for these goods as fully as possible, but also to prevent overstocking of the warehouse and the formation of excessively high costs associated with inventory management. Therefore, we propose to divide the group of upturned stocks, in turn, into three subgroups by the number of sales per month:

- 8 or more sales;

- $\quad$ from 4 to 7 sales;

- less than four sales.

Here we have shared the goods with respect to their sales per month. However, fast-moving stocks require weekly purchases, so it would be more accurate to present this classification relative to the average sales of goods per week, referring to the last fourth group of goods, the turnover of which is more than a month:

- more than one sale per week;

- $\quad$ one sale per week;

- $\quad$ less than one sale per week;

- less than one sale per month.

The division of goods into groups XYZ (vertically) implies the division of the whole set of goods into 3 groups relative to one of several criteria:

- $\quad$ stability of sales;

- the group's contribution to the total profit;

- $\quad$ percentage of total inventory value.

However, none of these (most popular) criteria fully corresponds to the specifics of the book trade, which is why in the book trade is very difficult to use the classic methods of sales forecasting.

The other two criteria ("the group's contribution to total profit" and "percentage of total inventory value) are also not well suited for a large bookstore, as this method involves some fluctuations related to changes in the volume or structure of inventories.

As a second criterion of the $\mathrm{ABC}-\mathrm{XYZ}$ analysis, we propose to use the retail price of the product. This criterion, in our opinion, is most suitable, because, firstly, the price is absolute, not relative value 
and any changes in the structure of the stock, each individual in the book trade I book will always belong to one specific group, and, secondly, the retail margin in large book trade enterprises, as a rule, is set automatically and is the same percentage. Therefore, we believe that the classification criterion should not be the profit derived from the sale of a particular publication, but the retail price of the product, as it will significantly simplify the analysis.

Taking into account the above, we propose to divide stocks by this criterion not by three, as in the classic $A B C-X Y Z$ analysis, but by four groups by the value of the goods:

- below 150 rubles;

- from 150 to 300 rubles;

- from 301 to 700 rubles;

- more than 700 rubles.

It should be noted that this list is not exhaustive, and the classification may be re-indexed due to changes in the average prices of books.

So, the first group we include the most beneficial from a commercial point of view, subgroups of goods "VI", "VF" and "EI". Goods belonging to this group bring the maximum profit at the expense of high cost and frequent sales - their constant existence in a trading floor is very important for the enterprise of retail trade. It should be noted that in the quantitative dimension, there are not many goods belonging to this group, therefore, buying them in excess, the company does not bear significant costs for transportation and storage. Thus the enterprise of retail trade is practically insured from the fact that these goods should be written off.

If the purchased goods are not sold before the time of the next order, they are likely to be sold in the near future, and with a decrease in sales of a particular product initially assigned to this group, subsequently, it will automatically move to another group with less turnover and will, accordingly, be purchased in smaller quantities. We offer to maintain a constant stock of goods of this group at the level of average consumption for the interval between deliveries plus 3 standard deviations from the average sales volume.

The second group includes subgroups "ay", "AZ", "BX", "BY", "CW", " CX. The availability of products of this group is also very important for profit and maintain a high level of customer service, so we offer to maintain a constant stock of these products at the level of average consumption for the interval between deliveries plus 2 standard deviations from the average sales volume.

The third group we include the least profitable of the subgroup "BZ", "CZ" and "BY". We believe that a constant stock of these goods should be maintained at the average cost per delivery interval plus 1 standard deviation from the average sales volume.

Thus, according to our proposed method, the entire set of reserves, we can divide into 6 groups, 3 of which, the most rapidly reversible, include 12 subgroups.

Thus, on the basis of deep study of the existing models and own experience of work at the bookselling enterprise, we offer an author's technique of management of stocks for the enterprises of book trade. This technique is based on combining the method of "3 Sigma" and ABC-XYZ analysis to divide goods into twenty groups by two features and finding the exact size of the stock (relative to the average consumption) for each group.
Table 2 - Indicators for calculating the volume of the order of different groups of goods by the author's method

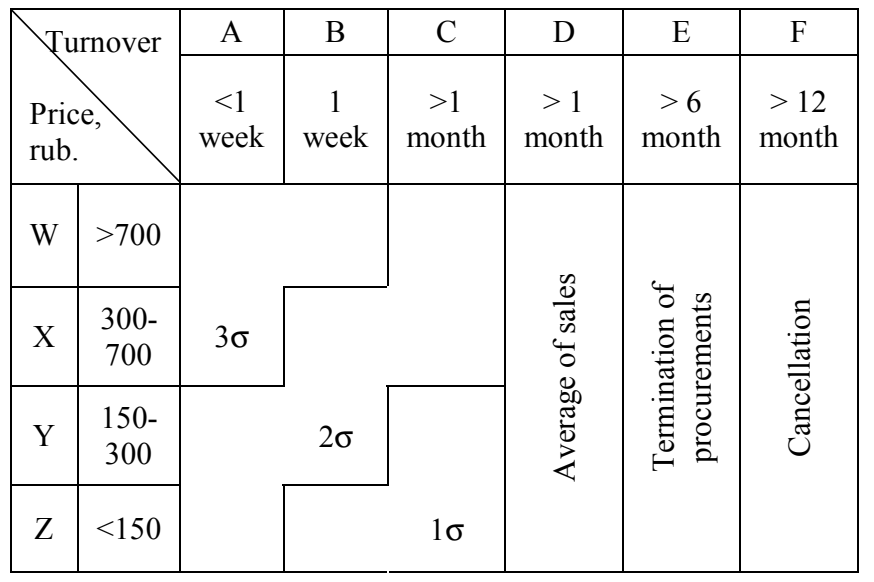

\section{CONCLUSION}

It is possible to optimize stocks only with the use of modern ERP and WMS systems. However, here it is necessary to carefully approach the use of Western approaches to managing the logistics of the enterprise. For example, the well-known model JIT ("Just in time"), which involves the virtual complete refusal to form insurance reserves can't be used in its purest form in the conditions of Russian regions.

One of the most important problems that is often ignored by many scientists and entrepreneurs is the problem of remoteness of suppliers from consumers. It should be noted here that most modern procurement technologies were invented and introduced for the first time in Japanese firms and with great difficulties were introduced into the practice of Canadian and American companies, whose suppliers, like many Russian enterprises, are located relatively far away. In Russia, the problem of remoteness of suppliers is exacerbated by the lack of infrastructure and a lack of multimodal carriers capable of organizing the process of delivery to remote regions by different modes of transport.

In a much more favorable environment are such industrialized countries as, for example, the United Kingdom and Japan. Therefore, even taking into account the fact that they are island States of a meridianally elongated shape, the distance between cities there, as a rule, does not exceed 300-500 kilometers, that with developed infrastructure, including high-speed highways, allows you to deliver goods within a few hours. Therefore, when sending the order in the morning, the buyer can be sure that by the evening his order will be picked up, shipped and delivered to his warehouse.

For comparison, it can be noted that the distance between Moscow and Vladivostok is more than 13 thousand kilometers. In the absence of high-speed trains and autobahns in many directions, the time of delivery of goods from Moscow to the regions can be calculated in weeks.

Most of the major suppliers are concentrated in the European part of Russia, therefore, enterprises located in the Asian part (on which there are many large cities) bear high costs for the transportation of goods from their suppliers. This problem is especially acute for those companies for which, at considerable geographical distance, the speed of delivery is important - such enterprises have to resort to 
expensive air transportation. The cost of delivery increases even more if it is necessary to transport goods by several modes of transport.

It is obvious that the only way to compensate for the length and the high cost of transportation is to form a reasonable amount of strass stock. First of all, this applies to the most popular and profitable positions. Thus, companies should not abandon modern Western systems of inventory control, but to use them it is necessary taking into account the existing economic conditions

The same applies to other aspects of booksellers ' activities in the regions. It is not necessary to reduce the cost of marketing - you need a more accurate distribution of marketing efforts, which will allow on the one hand to identify the existing demand, and the other hand to stimulate it. It is necessary to accurately predict demand, and if possible (for example, when using loyalty cards) - the identification of each individual buyer and the development of individual offers and loyalty programs based on his preferences.

The overall management of the supply chain and the use of different distribution channels are also important. Bookselling networks should not limit themselves to the opening of points of sale of the same format: in addition to large flagship stores, it is worth opening boutiques in shopping centers and other places of congestion, small shops in residential areas. Much attention should be paid to the development of their own online stores, as well as trade and brand promotion in social networks.
Summing up the above, it can be noted that, despite the crisis in the economy and the emergence of new electronic media, bookselling remains a promising area of business. The key to success here is the use of new sales channels and communications, as well as the use of modern systems and models of inventory management associated with qualitative forecasting of demand.

\section{References}

[1] Zdrestova-Zakharenkova S. V., Danilova A. S. "The role of logistics in managing the efficiency of a trading company" [Rol' logistiki v upravlenii effektivnost'yu torgovogo predpriyatiya]. p.158-161 ./Logisticheskie sistemy v global'noi ekonomike [Elektronnyi L69 resurs] : materialy VI Mezhdunar. nauch.-prakt. konf. (14-15 marta. 2016 g., Krasnoyarsk) : elektron. sb. / Sib. gos. aerokosmich. un-t. Krasnoyarsk, 2016. - Elektron. tekstovye dan. (1 fail, 9,8 MB). Sistem. trebovaniya: Internet Explorer; Acrobat Reader 7.0 (ili analogichnyi produkt dlya chteniya failov formata .pdf). - Rezhim dostupa: http://sibsau.ru/index.php/nauka-i-innovatsii/ nauchnyemeropriyatiya/konferentsii-sibgau/logisticheskie-sistemy-v-globalnojekonomike, svobodnyi. - Zagl. s ekrana.

[2] Grigor'ev V.V. "The book market of Russia. Status, trends and prospects of development. Industry report" [Knizhnyi rynok Rossii. Sostoyanie, tendentsii i perspektivy razvitiya. Otraslevoi doklad] / a. - M. Federal'noe agentstvo po pechati i massovym kommunikatsiyam, 2015.

[3] Grigor'ev V.V. "The book market of Russia. Status, trends and prospects of development. Industry report" [Knizhnyi rynok Rossii. Sostoyanie, tendentsii i perspektivy razvitiya. Otraslevoi doklad] / a. - M.: Federal'noe agentstvo po pechati i massovym kommunikatsiyam, 2016. 